Original Research Article

\title{
A comparative analysis of generic prescribing patterns among teaching and non-teaching clinicians in Nellore, India
}

\author{
Naveen Choudary Gorantla, Sree Nagamani Penupothu*
}

Department of Pharmacology, ACSR Government College, Nellore, Dr Ntruhs, Andhra Pradesh, India

Received: 08 March 2018

Revised: 12 March 2018

Accepted: 15 March 2018

*Correspondence to:

Dr. Sree Nagamani Penupothu, Email: nagamanni@gmail.com

Copyright: (C) the author(s), publisher and licensee Medip Academy. This is an openaccess article distributed under the terms of the Creative Commons Attribution NonCommercial License, which permits unrestricted noncommercial use, distribution, and reproduction in any medium, provided the original work is properly cited.

\begin{abstract}
Background: The aim was to study the prescribing patterns of clinicians working in two different settings i.e. Teaching clinicians (clinicians working in teaching hospital) and Non-teaching clinicians (clinicians involved only in private practice).

Methods: A comparative cross sectional study was carried out for a period of 6 months in two settings. The study is confined to teaching clinicians comprising of qualified medical practitioners in ACSR Government Medical College (ACSR GMC) and Non-teaching clinicians of qualified medical practitioners in private health sector (PMPs). 450 prescriptions were collected from clinicians belonging to various departments of ACSR GMC and 450 prescriptions from private practitioners of Nellore city. Data was coded and entered in MS Excel. Data was analyzed on EPI INFO version 3.5.4.

Results: In this study it was found that teaching clinicians prescribed 146 $(12.85 \%)$ drugs by generic name, whereas non-teaching clinicians prescribed 112 $(8.75 \%)$ drugs by generic name.

Conclusions: The findings of the present study indicate that the drugs prescribed by the generic names were remarkably less in both teaching and non teaching clinicians. This indicates a need for improving the generic prescribing patterns in both the settings.
\end{abstract}

Keywords: Branded drugs, Generic drugs, Non teaching practitioners, Prescription, Teaching practitioners

\section{INTRODUCTION}

A generic drug is a medication created to be the same as an existing approved brand-name drug in dosage form, safety, strength, route of administration, quality, and performance characteristics. ${ }^{1}$ Use of generic medicines significantly reduces the cost of medicines to both governments and patients. ${ }^{2}$ Generic medicines are those produced without a license from the innovator company when the patent or other market exclusivity rights on the innovator product has expired. ' 'Generic' should be applied to the chemical or pharmacological group of the component. ${ }^{3}$ Brand names are registered and are protected by law. Table 1 clarifies the nomenclature of drugs. ${ }^{4}$

According to Puneet et al, merits of branded and generic drugs are summarized in Table $2 .^{5}$

Generic medicines use the same active ingredients as brand-name medicines and work the same way, so they have the same risks and benefits as the brand-name medicines. ${ }^{1}$ Regardless of discrepancies in their precise legal definition, generic drugs are widely available worldwide, represent the majority of drug regulatory work in most countries, and are the most common approach to moderating pharmaceutical expenditure. ${ }^{6}$ Generic drugs 
are usually sold for significantly lower prices than their branded equivalents and at lower profit margins. ${ }^{7}$ Gary Buehler states that the reason generic manufacturers can sell the drugs less expensively is because they don't have to repeat the expensive safety and effectiveness testing that brand companies have already conducted. ${ }^{8}$ When multiple generic companies market a single approved product, market competition typically results in prices about $85 \%$ less than the brand-name. ${ }^{1}$ The Indian Medical Council (Professional conduct, Etiquette and Ethics) Regulations, 2002, state that "Every physician should, as far as possible, prescribe drugs with generic names and he/she shall ensure that there is a rational prescription and use of drugs." Health care providers frequently prescribe brand-name medications when generic versions are available; greater use of generic drugs could result in better long-term adherence to essential therapies. ${ }^{10}$ So this study has been conducted in both the clinical settings to assess the prescription of generic drugs.

Table 1: Nomenclature of drugs.

\begin{tabular}{|lll|}
\hline $\begin{array}{l}\text { Chemical } \\
\text { name }\end{array}$ & $\begin{array}{l}\text { Non- } \\
\text { proprietary } \\
\text { name }\end{array}$ & Proprietary name \\
\hline $\begin{array}{l}\text { Acetyl } \\
\text { salicylic acid }\end{array}$ & Aspirin & $\begin{array}{l}\text { Ecospirin (USV, India) } \\
\text { Disprin (Rickett and } \\
\text { Benckiser, India) }\end{array}$ \\
\hline $\begin{array}{l}\text { Aminobenzyl } \\
\text { penicillin }\end{array}$ & Ampicillin & $\begin{array}{l}\text { Biocillin (Biochem } \\
\text { Pharma, India) } \\
\text { Synthocillin (PCI, } \\
\text { India) }\end{array}$ \\
\hline
\end{tabular}

Table 2: Comparison between branded drugs and generics.

\begin{tabular}{|lll|}
\hline Issue & Branded & Generics \\
\hline Quality & $\begin{array}{l}\text { Expected to be } \\
\text { better in quality } \\
\text { than generic }\end{array}$ & $\begin{array}{l}\text { Expected to provide } \\
\text { the same quality as } \\
\text { branded }\end{array}$ \\
\hline \multirow{2}{*}{ Cost } & $\begin{array}{l}\text { Branded drugs set } \\
\text { the benchmarks for } \\
\text { cost }\end{array}$ & $\begin{array}{l}\text { Generics are } \\
\text { significantly } \\
\text { cheaper }\end{array}$ \\
\hline
\end{tabular}

\section{METHODS}

After approval from Institutional Ethics Committee, ACSRGMC, Nellore, a comparative cross sectional study was conducted for a period of 6 months in 2 different settings i.e. teaching clinicians in ACSR Government Medical College, Nellore and non-teaching clinicians from private sector in Nellore.

\section{Inclusion criteria}

- Qualified medical practitioners in ACSR Government Medical College, Nellore (Teaching clinicians).
- Qualified medical practitioners in Private health sector (PMPs) or (Non-teaching qualified clinicians).

\section{Exclusion criteria}

- $\quad$ Rural medical practitioners

- Homeopathy doctors

- $\quad$ Ayurvedic doctors and traditional healers

\section{Study period}

The study was conducted in Nellore city and ACSR Government Medical College, Nellore between March 2017 and August 2017. In Nellore there are about 70 registered private clinics and about 80 nursing homes. All together there are around 350-400 qualified doctors practicing in private sector. ACSR Government Medical College, Nellore is a tertiary hospital having 750 beds with around 800 out-patients per day including all specialties.

\section{Estimation of sample size}

The sample size is estimated using the prevalence of generic drug prescribing in the previous studies. ${ }^{11,12}$ The prevalence of generic drug prescribing was around $63 \%$ in various studies done in India. Hence the sample required for the study is calculated by considering the prevalence of generic drug prescription as $63 \%$. With an allowable error of $5 \%$ and $95 \%$ precision rate the sample size is calculated as 896 which were rounded to 900 prescriptions. Hence 450 prescriptions were collected from clinicians belonging to various departments of ACSR GMC and 450 prescriptions from private practitioners of Nellore city.

\section{Data collection}

We visited the clinicians to seek formal permission, explain the nature of the study and build rapport. The practitioners were informed that the data will be collected on common diseases prevalent in the area and the drugs being used for that purpose, but not about the true study objective to minimize observation bias. Study variables related to the provider includes whether the clinicians prescribed generic drugs or not. Data was coded and entered in MS EXCEL with the help of a statistician to minimize the data entry errors. Data analyzed on EPI INFO version 3.5.4. The different variables are expressed as frequencies and percentages. Chi square test was used as a test of significance $(\mathrm{P}<0.05)$.

\section{RESULTS}

During the study period 900 prescriptions were collected, out of these 450 were from teaching clinicians (ACSR GMC) and 450 from Non-teaching clinicians (PMPs).

The 450 prescriptions by teaching clinicians had a total of 1136 drugs; whereas 450 prescriptions by non-teaching clinicians had a total of 1280 drugs as shown in Table 3. 
Number of drugs prescribed by generic name was compared in both the settings. Teaching clinicians prescribed 146 drugs $(12.85 \%)$ by generic name, whereas non-teaching clinicians prescribed 112 drugs $(8.75 \%)$ as seen in Table 3.

Table 3: Comparative analysis of prescriptions.

\begin{tabular}{|lll|}
\hline & $\begin{array}{l}\text { Teaching } \\
\text { clinicians } \\
\text { (ACSR GMC } \\
\text { and H) }\end{array}$ & $\begin{array}{l}\text { Non- } \\
\text { teaching } \\
\text { clinicians } \\
\text { (PMPs) }\end{array}$ \\
\hline No. Of prescriptions & 450 & 450 \\
\hline $\begin{array}{l}\text { No of drugs } \\
\text { prescribed. }\end{array}$ & 1136 & 1280 \\
\hline $\begin{array}{l}\text { No of drugs prescribed } \\
\text { by generic name. }\end{array}$ & 146 & 112 \\
\hline $\begin{array}{l}\text { Chi square 8.17, d.f 1, p }<0.003 \text { statistically } \\
\text { significant }\end{array}$ & \multicolumn{2}{|l|}{$(12.85 \%)$} \\
\hline
\end{tabular}

Comparatively, teaching clinicians (12.85\%) prescribed more generic drugs than non teaching clinicians $(8.75 \%)$ as shown in Figure 1.

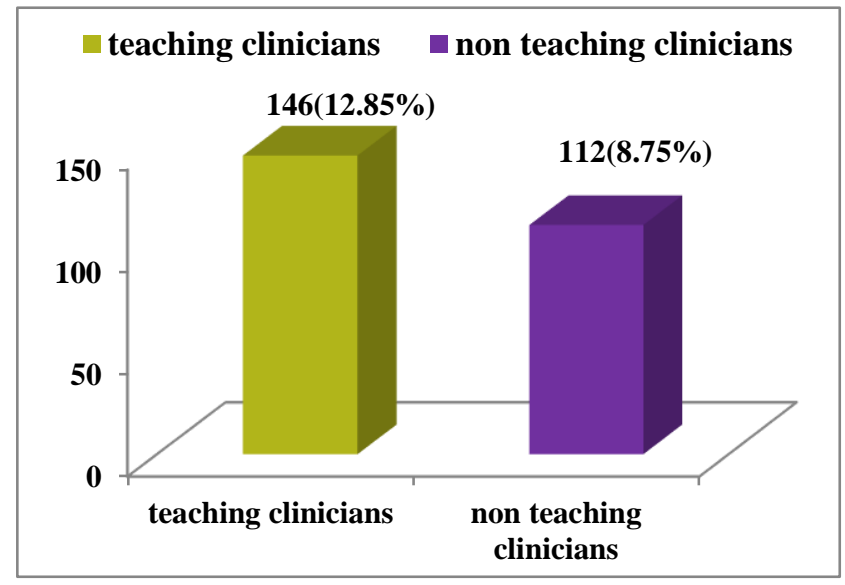

Figure 1: No. of drugs prescribed by generic name.

\section{DISCUSSION}

In this study it was found that teaching clinicians prescribed $12.85 \%$ drugs by generic name, whereas nonteaching clinicians prescribed $8.75 \%$ drugs by generic name. Phalke VD, et al, in their study showed that none of the doctors wrote the generic name of the drug. ${ }^{13}$ Y.M. Irshaid et al, found that only $15 \%$ of the prescriptions mentioned the generic name. ${ }^{14}$ Anuja A Pandey et al, found only $7.4 \%$ of paediatric outpatient prescriptions from Pune had clearly mentioned generic name while use of brand name was a universal practice. ${ }^{15}$ It was observed in the study by Manoj kumar et al, that generic preparations $(67.25 \%)$ were more commonly prescribed than branded medicines by Government Doctors whereas only $4.25 \%$ by Private Practioners. ${ }^{16}$
In this study, teaching clinicians prescribed generic drugs more when compared to non teaching clinicians. Practice of using generic names gives an advantage to the pharmacist also to dispense the cheapest drug or the one which is available.

Major challenges for the greater penetration of generics include public and health care worker perception and quality issues. ${ }^{17}$ Quality assurance with the use of good manufacturing practices and adequate supervision by regulatory authorities is of paramount importance to ensure bio-equivalence, and therefore the safety and efficacy of generic medications. ${ }^{17}$

Clinicians should maintain a high rate of generic prescribing. Education of doctors, pharmacists, and patients regarding benefits and cost effectiveness of generic drugs should be implemented.

\section{ACKNOWLEDGEMENTS}

Authors would like to thank their Professor and Head of Department of Pharmacology, Dr. V.L.M. Raman and Dr. Y. Lakshmi Associate Professor for their valuable guidance. Authors also thank Dr. Sowmya Sudha, Assistant Professor, Department of Community Medicine for her suggestions.

Funding: No funding sources

Conflict of interest: None declared

Ethical approval: The study was approved by the Institutional Ethics Committee of ACSR GMC, Nellore, India

\section{REFERENCES}

1. US FDA Generic drug facts. Available at: https://www.fda.gov/Drugs/ResourcesForYou/Consu mers/BuyingUsingMedicineSafely/GenericDrugs/uc m167991.htm

2. WHO Drug Information Generic medicines. 2016;30(3):370. Available at: http://apps.who.int/medicinedocs/documents/s23010e n/s23010en.pdf

3. Tripathi KD. Essentials of Medical Pharmacology. $7^{\text {th }}$ Edition. Jaypee Brothers Medical Publishers, New Delhi; 2014:3.

4. Sharma HL, Sharma KK. Introduction Table 1.1. In: Sharma HL, Sharma KK, Sharma \& Sharma's Principles of Pharmacology $3^{\text {rd }}$ Ed. Paras Medical Publishers, Hyderabad; 2017:3.

5. Dhamija P, Sharma PK, Kalra S. Only generics (drugs/names): Is India ready?. Indian journal of endocrinology and metabolism. 2015 Sep;19(5):541.

6. The Impact of Implementation of ICH Guidelines in Non-ICH Countries Report of a WHO Meeting Geneva, 13-15 September 2001. World Health Organization Geneva; 2002. Available at: http://apps.who.int/medicinedocs/en/d/Jh2993e/8.htm 
7. US Food and Drug Administration. Savings from generic drugs purchased at retail pharmacies. updated 6/26/2009, Available at: http://www. fda. gov/Drugs/EmergencyPreparedness/Bioterrorismand Drug Preparedness/ucm134205. htm; 2005.

8. US FDA, Saving money on prescription drugs. Available at: https://www.fda.gov/Drugs/ResourcesForYou/ucm13 4215.htm

9. Indian Medical Council (Professional Conduct, Etiquette and Ethics) Regulations, 2002. [cited 2015 Nov 27]. Available at: http://www.mciindia.org/Rules-and-

Regulation/Ethics\%20Regulations-2002.pdf.

10. Choudhry NK, Denberg TD, Qaseem A. Improving adherence to therapy and clinical outcomes while containing costs: opportunities from the greater use of generic medications: best practice advice from the Clinical Guidelines Committee of the American College of Physicians. Annals of internal medicine. 2016 Jan 5;164(1):41-9.

11. Bhatnagar T, Mishra CP, Mishra RN. Drug prescription practices: a household study in rural Varanasi. Indian J Prev Soc Med. 2003;34(1):33-9.

12. Dutta A, Chakraborty S. Practice of rational drug uses in a rural area of $24 \mathrm{pgs}$ (s) in West Bengal. Journal of Advanced Pharmaceutical Technology \& Research. $2010 \mathrm{Jul} ; 1(3): 358$.

13. Phalke VD, Phalke DB, Syed MA, Mishra A, Sikchi $\mathrm{S}$, Kalakoti P. Prescription writing practices in a rural tertiary care hospital in Western Maharashtra, India. The Australasian medical Journal. 2011;4(1):4.

14. Irshaid YM, Al Homrany M, Hamdi AA, AdjeponYamoah KK, Mahfouz AA. Compliance with good practice in prescription writing at outpatient clinics in Saudi Arabia. Eastern Mediterranean Health Journal, 2005;11(5/6):922-28.

15. Pandey AA, Thakre SB, Bhatkule PR. Prescription Analysis of Pediatric Outpatient Practice in Nagpur City. Indian J Community Med. 2010 January;35(1):70-3.

16. Saurabh MK, Yadav AK, Gupta P, Singhai A, Saurabh A. Comparative study of prescribing behaviors of government doctors of teaching hospital and private practitioners in Jhalawar City (Rajasthan). J. Pharm. Sci. and Res. 2010;2(4):208-15.

17. G de LL. cost comparison and economic implications of commonly used originator and generic chemotherapy drugs in India, Annals of Oncology. September 2013;24(5).

Cite this article as: Gorantla NC, Penupothu SN. A comparative analysis of generic prescribing patterns among teaching and non-teaching clinicians in Nellore, India. Int J Basic Clin Pharmacol 2018;7:622-5. 